How to cite: Angala, H.A.N., Tandlich, R., Ngqwala, N.P., Zuma, B.M. (2019) Efficiency of a Decentralised System in the Treatment of Rainwater in South Africa. 2019 "Air and Water - Components of the Environment" Conference Proceedings, Cluj-Napoca, Romania, p. 1-8, DOI: 10.24193/AWC2019_01.

\title{
EFFICIENCY OF A DECENTRALISED SYSTEM IN THE TREATMENT OF RAINWATER IN SOUTH AFRICA
}

\section{Hallo Angaleni Nameya ANGALA ${ }^{1}$, Roman TANDLICH ${ }^{1}$ 冈, Nosiphiwe P. NGQWALA ${ }^{1}$, Bonugmusa Msisi ZUMA ${ }^{2}$}

\author{
DOI: 10.24193/AWC2019_01
}

\begin{abstract}
Rainwater harvesting provides a low-cost and flexible alternative for drinking water provision in decentralised settings in urban and rural areas of developing countries. Efficiency of a decentralised low-cost filter, i.e. Grifaid® filter, in the treatment of rainwater harvested at various sites at the Rhodes University campus in South Africa, was tested in this study. Sampling took place between beginning of August and end of October 2016. The treatment efficiency results indicate that Grifaid $®$ filters remove 100 $\%$ of the faecal bacterial indicators and $100 \%$ of turbidity from the treated rainwater. The $\mathrm{pH}$ values of the treated rainwater remain unaffected by the Grifaid ${ }^{\circledR}$ treatment. Ammonium and aluminium concentrations, measured in the harvested rainwater, were not considered dangerous for human health. However, nitrate concentrations surpassed the World Health Organisation of $50 \mathrm{mg} / \mathrm{L}$ and will require to be treated using ion exhcnage in further research.
\end{abstract}

Keywords: Grifaid® filter, E. coli, chemical indicators, university campus, rainwater.

\section{INTRODUCTION}

Rural areas in developing countries often lack conventional water supply infrastructure. Collection, storage and use of rainwater is often described by one term, namely rainwater harvesting (RWH). It can be considered an alternative solution for water provision in areas where piped water is lacking (Baguma et al. 2010; United Nations Environment Programme, 2016). Besides rural communities, RWH can be used to supply potable water to most informal communities in urban settings (United Nations Environment Programme, 2016). Installation of RWH systems in urban settings can also be done in developed areas. In all these settings, the harvested rainwater can be used for domestic purposes, such as drinking and cooking (Kahinda and Taigbenu, 2011; Opare, 2012). Literature for the African continent shows that RWH has been a common practice in South Africa (Kahinda et al., 2007; Malema et al., 2018), Namibia (Sturm et al., 2009), Nigeria (Ishaku et al., 2012), Uganda (Baguma and Loiskandl, 2010), Ghana (Opare, 2012) and Zimbabwe (Katsii et al., 2007).

\footnotetext{
${ }^{1}$ Faculty of Pharamcy and Rhodes University Biotechnology Innovation Centre, Rhodes University, Artillery Road, P.O. Box 94, Grahamstown 6140, South Africa, r.tandlich@ru.ac.za; roman.tandlich@ gmail.com.

${ }^{2}$ Lugaju Innovations, Water Sciences Unit, 21 St. Georges Street, Southernwood, East London 5201, South Africa.
} 
The current study took place at the Rhodes University (RU) campus which is located in the small city of Makhanda/Grahamstown in the Eastern Cape Province, South Africa. The area has been designated as water disaster area for more than a year (Nondlazi et al., 2017). Water scarcity and the El-Niño drought since 2015, along with infrastructural challenges, have resulted in the primary and secondary water scarcity to the RU staff and students. Since at least 2012, RU has undertaken various initiatives to increase water self-sufficiency (Rygaard et al., 2011) through various initiatives, e.g. installation of RWH systems across campus. These systems are used as the source of water for flushing toilets or for drinking after boiling, when municipal potable water supply is interrupted to RU campus. At the time of the writing of this article, RU has been undertaking drilling of boreholes at the university campus and tanks were installed around campus to provide access to drinking water and untreated borehole water for toilet flushing. However, the RWH systems remain the most established systems for non-municipal water supply on RU campus, students and staff are aware of them; and make regular use of them.

At RU and beyond, harvested rainwater is generally used for drinking and cooking (Kahinda \& Taigbenu, 2011; Opare, 2012). In these domestic uses, the challenge is often that microbial and chemical quality of rainwater is unknown and/or the respective regulatory guidelines are not met (Malema et al., 2018). Domestic uses of such rainwater create a potential health hazard for the consumer. As a result, RWH and use must be accompanied by treatment and regular monitoring of the quality of the harvested rainwater. Examples of treatment options are disinfection methods and reverse osmosis (Malaeb and Ayoub, 2011; Gupta et al., 2012). There are also smaller point-of-use filtration systems which can be used for raw rainwater treatment, e.g. Grifaid® filter (Grifaid/Save Water Trust, Cleadon, Sutherland, United Kingdom). A Grifaid ${ }^{\circledR}$ filter was tested in the current study as treamtent option for the provision of potable rainwater that was harvested at the RU campus. The RU campus and the ongoing initiatives, aimed at increasing the water self-reliance of the university which is in a partially isolated geographical area, provide a good platform for the testing of the decentralised treatment systems for water-scarce areas (Angala, 2018).

The specific filter used in this study is a hand-operated system. The Grifaid® filters were used as shown in Fig. 1a or enclosed in a custom-made casing for protection against theft, weather elements and to ensure communal use of the filter (Fig. 1b). The logic behind the design is to ensure that the filter can be attached to a rainwater harvesting tank, without the user being able to remove it, while still allowing it to be functional. The container was also designed to be animal-proof so that disease-carrying animals, such as rats, do not come into contact with the Grifaid@ ${ }^{\circledR}$ filter. The treatment efficiency was assessed by examining the removal of indicator microorganisms and physico-chemical parameters from the rainwater harvested at the RU campus.

\section{DATA AND METHODS}

Ten sampling sites were selected around the RU campus, where RWH systems are installed and the Grifaid® filter treatment efficiency counld be tested. Details of the ten 
sampling sites are described in Table 1, with the indication about any treatment system already present. Closed system refers to the closed rainwater harvesting tank and direct connection between the catchment and the storage tank. The roofing material used for the buildings was tiled roofs and majority of the catchments were covered by plant debri and animal faecal material, i.e. indicating potential sources of contamination of the harvested rainwater. In addition, the roofing material would not have provided any sterilisation/treatment upon contact with the rainwater (Tandlich et al., 2012).

Rainwater was sampled at all ten sites and analysed for the thermotolerant $E$. coli and selected physiochemical properties to determine the treatment efficiency of the Grifaid ${ }^{\circledR}$ filter. Sampling was conducted weekly over a period of three months bewteen the beginnign of August and the end of October 2016. Sampling bottles (5 litre plastic bottles) were washed and chemically sterilised with successive washes with detergent, tap water, deionsed water and bleach/70 \% ethanol (Spellbound Labs, Port Elizabeth, South Africa/ Chemstores, Rhodes University). Sterility of a small number of sampling containers was conducted before each sampling run by rinsing them with sterile water and performing membrane filtration for E. coli (see below).

a)

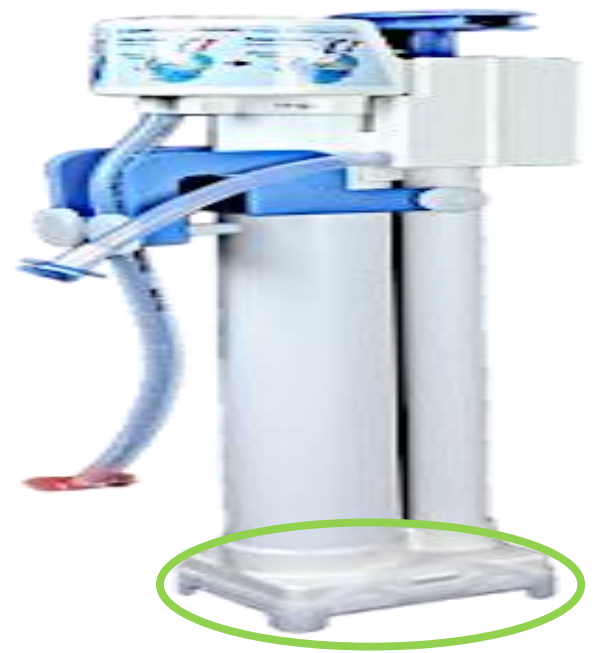

b)

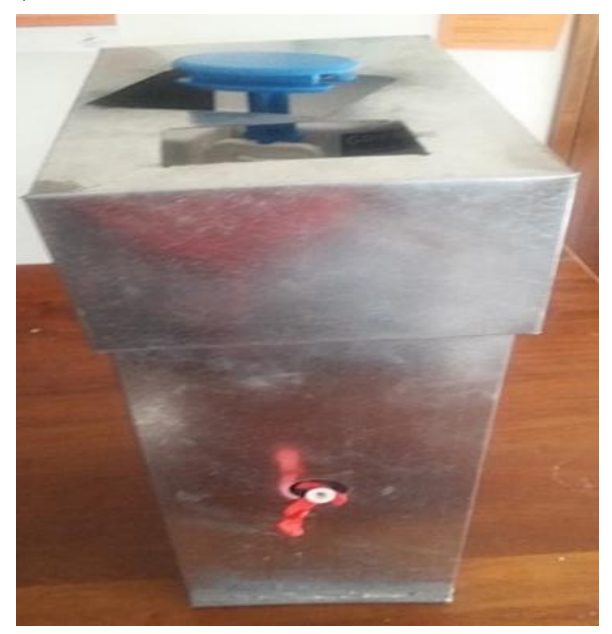

Fig. 1. Picture of Grifaid $₫$ filter (Fig. 1a) with suction and uptake of the water to be treated at the bottom (see green circle; adapted from Grifaid.org, 2017; no copyright applies to the best of the authors' knowledge). Depiction of the Grifaid ${ }^{\circledR}$ filter mounted inside protective casing when attached to a RWH system (Fig. 1b). Both depictions are from Rhodes University campus.

At the respective sampling site and on a given sampling occasion, we used gloves which were sterilised with $70 \%$ ethanol. Next, the outer area of the rainwater storage tank tap, as well as the top of the sampling bottle, were disinfected with $70 \%$ ethanol. The taps were open and the sampling bottles were filled to the brim with rainwater from the mid-stream. Samples were then transported on ice to the microbiological laboratory in the faculty of Pharmacy of RU for analysis. Concentrations of 
thermotolerant E. coli was measured as outlined by Tandlich et al. (2014), while the chemical parameters were measured using the methods similar to those of Nondlazi et al. (2017). The measured physico-chemical parameters included $\mathrm{pH}$, turbidity, concentrations of ammonium, nitrate and aluminium. Chemical parameters were measured using the spectrophotometric kits purchased from Merck Pty. Ltd. (Cape Town/Johannesburg South Africa) and the Shimadzu 1240 Mini UV/VIS spectrophotometer (Shimadzu, Johannesburg South Africa).

Treatment of the harvested rainwater was performed in the laboratory by handpumping the rainwater from a sterilised contained into another sterilised container using the Grifaid ${ }^{\circledR}$ filter. Sampled from both harveted rainwater and the treated rainwater were collected and analysed for $E$. coli and physico-chemical parameters. Efficiency of treatment was assessed by determining the statistically significant differences bewteen the composition of the sampled/harvested rainwater and the composition of the rainwater treated using the Grifaid ${ }^{\circledR}$ filter. Mann-Whitney test was performed as one-way and two-way test at $5 \%$ level of significance, (see https://www.socscistatistics.com/tests/mannwhitney/Default2.aspx for details). If statistically significant difference was detected for the mean values (all values) of a given parameter, then the removal efficiency $(R E)$ for the filtration treatment was calculated for individual parameters as shown in Equation (1).

$$
R E(\%)=\left(\frac{\operatorname{Inf}-E f f}{\operatorname{Inf}}\right) \times 100
$$

In Equation (1),

Inf is the average value/concentration of the given parameter in the harvested rainwater, while

Eff is the average value/concentration of the given parameter in the treated rainwater.

Table 1. Site descriptions in regards to filtration features installed per site which were sampled between August and October 2016

\begin{tabular}{|c|l|c|c|c|}
\hline $\begin{array}{c}\text { Site } \\
\text { Number }\end{array}$ & \multicolumn{1}{|c|}{ Location } & $\begin{array}{c}\text { First flush } \\
\text { diverter }\end{array}$ & Closed system & $\begin{array}{c}\text { Post-harvest } \\
\text { Filter }\end{array}$ \\
\hline $\mathbf{1}$ & Allan Grey House & No & Yes & No \\
\hline $\mathbf{2}$ & Prince Alfred House & No & Yes & Yes \\
\hline $\mathbf{3}$ & $\begin{array}{l}\text { Mathematics } \\
\text { department }\end{array}$ & No & Yes & No \\
\hline $\mathbf{4}$ & Drostdy dining hall & No & Yes & No \\
\hline $\mathbf{5}$ & Hamilton Building & No & Yes & Yes \\
\hline $\mathbf{6}$ & Botha House & No & Yes & No \\
\hline $\mathbf{7}$ & Matthews House & No & Yes & No \\
\hline $\mathbf{8}$ & Cory House & No & Yes & No \\
\hline $\mathbf{9}$ & College House & No & Yes & No \\
\hline $\mathbf{1 0}$ & Hobson House & No & Yes & No \\
\hline
\end{tabular}

Units of the parameters are colony-forming units per 100 millitres of samples water for concentrations of E. coli (CFUs/100 mL), nephelometric turbidity units for turbidity (NTU) and milligrams per litre for the chemical parameters of harvested rainwater $(\mathrm{mg} / \mathrm{L})$. 


\section{RESULTS AND DISCUSSIONS}

As it can be seen in Table 2, treatment of the harvested rainwater with the Grifaid $^{\circledR}$ filter resulted in the complete and statistically significant removal of E. coli and turbidity. Based on the values of these two parameters in the treated rainwater, the WHO guidelines for rainwater for drinking and domestic use were met (see WHO, 2011 Table 7.10 on page 149 for E. coli and pages 228-229 for turbidity). As a result, concentration of $E$. coli in the treated rainwater was below $0 \mathrm{CFUs} / 100 \mathrm{~mL}$, while turbidity was below $0 \mathrm{NTU}$ in the treated rainwater. The maximum concentration of thermotolerant $E$. coli in the harvested rainwater was equal to 246 CFUs/100 mL and it was shown to be an outlier based on Grubb's test for outlier at $5 \%$ level of significance (see https://www.graphpad.com/quickcalcs/grubbs2/ for details). Based on this result, only 29 values for the E. coli concentration were used for the calculation of the geometric mean concentration of thermotolerant $E$. coli in the harvested rainwater, i.e. $21 \mathrm{CFUs} / 100 \mathrm{~mL}$.

Table 2. Treatment efficiency data for Grifaid ${ }^{\circledR}$ filter

\begin{tabular}{|c|c|c|c|c|c|c|c|c|c|}
\hline \multirow[b]{2}{*}{ Parameter } & \multicolumn{4}{|c|}{ Harvested rainwater $($ Inf $)$} & \multicolumn{5}{|c|}{ Treated rainwater $(E f f)$} \\
\hline & 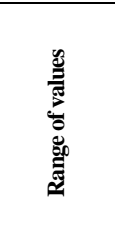 & 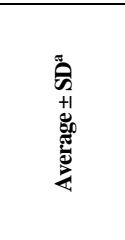 & 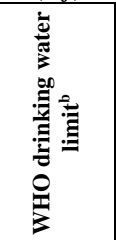 & 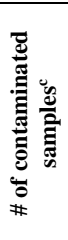 & 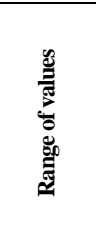 & 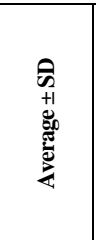 & 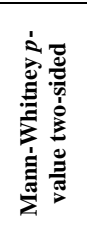 & 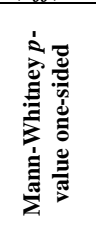 & $\stackrel{0}{2}$ \\
\hline E. coli $($ CFUs $/ 100 \mathrm{~mL})$ & $3-246$ & 21 & 0 & 30 & 0 & 0 & $9 \times 10^{-5}$ & $1.8 \times 10^{-4}$ & 100 \\
\hline \begin{tabular}{|l|} 
Turbidity (NTU) \\
\end{tabular} & $0.00-3.60$ & $0.86 \pm 0.99$ & $0-1$ & 9 & 0 & 0 & $<10^{-5}$ & $1.4 \times 10^{-3}$ & 100 \\
\hline pH & $6.6-7.7$ & 7.1 & $6.5-8.5$ & 0 & $6.6-7.7$ & 7.1 & $>0.100$ & $>0.100$ & 0 \\
\hline $\mathrm{NH}_{4}{ }^{+}(\mathrm{mg} / \mathrm{L})$ & $8.2-18.7$ & $10.9 \pm 2.70$ & $\begin{array}{c}\mathrm{NA}^{\mathrm{a}} \text { or } 35 \\
\mathrm{mg} / \mathrm{L}^{\mathrm{b}}\end{array}$ & 0 & $8.4-26.8$ & $\begin{array}{c}13.1 \pm \\
4.8\end{array}$ & $\begin{array}{c}0.425- \\
0.447\end{array}$ & 0.005 & 0 \\
\hline $\mathrm{NO}_{3}^{-}(\mathrm{mg} / \mathrm{L})$ & $21.1-70.7$ & $48 \pm 13$ & 50 & 14 & $\begin{array}{l}33.5- \\
138.8\end{array}$ & $63 \pm 21$ & $\begin{array}{c}0.242- \\
0.660\end{array}$ & 0.001 & 0 \\
\hline$A l^{3+}(\mathrm{mg} / \mathrm{L})$ & $0-0.11$ & $0.03 \pm 0.02$ & 0.10 & 1 & $0.01-4.9$ & $\begin{array}{c}0.28 \pm \\
0.91\end{array}$ & $\begin{array}{c}0.197- \\
0.795\end{array}$ & 0.004 & 0 \\
\hline
\end{tabular}

${ }^{a}$ Geometric mean was calculated for the concentration of thermotolerant E. coli. All other parameters are reported as arithmetic mean \pm standard deviation

${ }^{\mathrm{b}}$ No health-related limit has been proposed by the World Health Organisation.

${ }^{\mathrm{c}}$ An approximate limit of $35 \mathrm{mg} / \mathrm{L}$ of ammonium was proposed as the taste limit, i.e. above this concentration the taste of the harvested rainwater might be adversely affected by the $\mathrm{NH}_{4}{ }^{+}$ions presence.

The average turbidity in the harvested rainwater was equal to $0.86 \pm 0.99 \mathrm{NTU}$, which is comparable to values of $0.3 \pm 0.1$ to $2.6 \pm 3.1 \mathrm{NTU}$ as reported by Despins et al. (2009). This means that the standard deviation being higher than the average turbidity of rainwater is not uncommon and so the values from this study are comparable to observation made by other researchers. The treatment with Grifaid ${ }^{\circledast}$ filter had no effect on $\mathrm{pH}$ of the rainwater, but the $\mathrm{pH}$ values was within the acceptable limits from 6.5 to 8.5 as stipulated by WHO (2011, page 226).

Results for the removal of $E$. coli from rainwater in this study are in agreement with the results reported by Sallis (2010) and Naranjo and Gerba (2013). Grifaid ${ }^{\circledR}$ filter was supported as an efficient treatment method for the removal of microbial indicators by 
Kenya Water Institute (Muthama, 2012). To the best of the authors' knowledge, no reference values exist in literature on the removal of turbidity from rainwater by Grifaid $^{\circledR}$ filtration.

The results showed that for the first two months showed that there was no statistically significant difference between the ammonium concentration before and after filtration ( $p$-values $=0.425$ and 0.447 ). In month 3 , there was a release of ammonium from the filter and its was statistically significant ( $p$-value $=0.005$ ). There is no reference value for the ammonium concentration in rainwater as specified in respect of any negative health outcomes of drinking the harvested rainwater (WHO, 2011, as summarised on page 223). None of the samples contain ammonium in conentrations above $35 \mathrm{mg} / \mathrm{L}$ (WHO, 2011, page 223), i.e. that the taste of the harvested rainwater would not negatively affected by the presence of $\mathrm{NH}_{4}^{+}$.

In $47 \%$ of the harvested rainwater samples and in $70 \%$ of the treated rainwater samples, the nitrate concentration exceeded the WHO guideline of $50 \mathrm{mg} / \mathrm{L}$, which indicates that consumption of the harvested and treated rainwater can lead to methhaemoglobinaemia in infants (WHO, 2011, page 398). Results of the MannWhitney test at $5 \%$ level of significance showed that the nitrate concentrations in harvested and treated rainwater was not statistically significant different from 50 $\mathrm{mg} / \mathrm{l}$ ( $p$-value $=0.660$ in both cases). In month 1 , there was a release of nitrate from the filter and it was statistically significant ( $p$-value $=0.001$ ). The results for months 2 and 3 showed that for that there was no statistically significant difference between the nitrate concentration before and after filtration ( $p$-values $=0.242$ and 0.523 ). These results indicate that concentration of nitrates should be monitored on a regular basis at Rhodes University campus, in the harvested and treated rainwater. The Grifaid $^{\circledR}$ filter is not an ideal treatment method to remove the $\mathrm{NO}_{3}{ }^{-}$ions from harvested rainwater. Additional treatment with different methods such as anion exchange (Boutin et al., 2011) will have to be implemented as a matter of urgency.

All but one sample of the harvested rainwater contained the average concentration of aluminium which was always below the WHO recommended limit of $0.1-0.2 \mathrm{mg} / \mathrm{L}$ (WHO, 2011, page 311). The average $\mathrm{Al}^{3+}$ concentration in the treated rainwater was equal to $0.28 \pm 0.91 \mathrm{mg} / \mathrm{L}$, with $6.7 \%$ exceeding the $\mathrm{WHO}$ guideline of 0.1-0.2 mg/L for aluminium levels in drinking water (see Table 2). In months 1 and 2, there was no statistically significant difference between the aluminium concentrations before and after filtration ( $p$-value $=0.197$ and 0.795$)$. In month 3 , the results that for that there was a statistically significant release of aluminium from the treated rainwater during filtration $(p$-value $=0.004)$. Therefore, the Grifaid ${ }^{\circledR}$ filter is not efficient in the removal of $\mathrm{Al}^{3+}$ cations from rainwater. Further treatment and regular monitoring of the treated rainwater is a must, e.g. using ion exchange (Boutin et al., 2011), as the Grifaid ${ }^{\circledR}$ filter has limited to no ability to remove chemical components from the treated rainwater. 


\section{CONCLUSIONS}

RWH is an alternative to the provision of water, but results obtained indicate that harvested rainwater does not meet established consumption standards and that it thus requires further treatment before it can be safely used for domestic purposes. The treatment efficiency results indicate that Grifaid ${ }^{\circledR}$ filters remove $100 \%$ of the faecal bacterial indicators and $100 \%$ of turbidity from the treated rainwater. The $\mathrm{pH}$ value of the treated rainwater remains unaffected, while further treatment must be considered for the chemical indicators.

\section{ACKNOWLEDGEMENTS}

The authors would like to thank the Faculty of Pharmacy at Rhodes University and the Rhodes University Biotechnology Innovation Center for technical and logistical assistance, during the South African part of the study. Research described in the current study was part of Hallo Angala's Master of Science in Biotechnology degree and she was supported by funding from the German Academic Exchange Service (DAAD) and the Namibia Commission of Science and Technology (NCRST). The support of the funders is kindly acknowledged.

\section{REFERENCES}

1. Angala, H. A. N. (2018). Citizen science, treatment and microbial compliance monitoring in rainwater harvesting in Namibia. MSc thesis, Rhodes University, Grahamstown/Makhanda, South Africa.

2. Baguma D., Loiskandl W. (2010), Rainwater harvesting technologies and practices in rural Uganda: a case study. Mitigation Adaptation Strategy Global Change,15(4), 355-369. DOI: https://doi.org/10.1007/s11027-010-9223-4.

3. Baguma D., Loiskandl W., Darnhofer I., Jung H., Hauser M. (2010), Knowledge of measures to safeguard harvested rainwater quality in rural domestic households. Journal of Water and Health, 8(2), 334-345. DOI: https://doi.org/10.2166/wh.2009.030.

4. Boutin V., Butler C., Kesseli S., McCorry M.C. (2011) Improving water quality and sanitation in rural Namibian communities. Bachelor of Science thesis, Worcester Polytechnic Institute, Worcester, MA, USA.

5. Despins C., Farahbakhsh K., Leidl C. (2009), Assessment of rainwater quality from rainwater harvesting systems in Ontario, Canada. Journal of Water Supply: Research and Technology-AQUA, 48(2), 117-134.

6. Ishaku H.T., Majid M.R., Johar F. (2012), Rainwater harvesting: an Alternative to safe water supply in Nigerian rural communities. Water Resource Management, 26(2), 295-305. DOI: https://doi.org/10.1007/s11269-011-9918-7.

7. Kahinda J-M.M., Taigbenu A.E. (2011), Rainwater harvesting in South Africa: challenges and opportunities. Physics and Chemistry of the Earth, 36(14-15), 968976. DOI: https://doi.org/10.1016/j.pce.2011.08.011. 
8. Kahinda J-M.M., Taigbenu A.E., Boroto J.R. (2007), Domestic rainwater harvesting to improve water supply in rural South Africa. Physics and Chemistry of the Earth, 32(15-18), 1050-1057. DOI: https://doi.org/10.1016/j.pce.2007.07.007.

9. Katsii L., Siwadi J., Guzha E., Makoni F.S., Smits S. (2007), Assessment of factors which affect multiple uses of water sources at household level in rural Zimbabwe - A case study of Marondera, Murehwa and Uzumba Maramba Pfungwe districts. Physics and Chemistry of the Earth, 32(15-18), 1157-1166. DOI: https://doi.org/10.1016/j.pce.2007.07.010.

10. Malema M.S., Abia A.L.K., Tandlich R., Zuma B., Kahinda J.-M.M., Ubomba-Jaswa, E. (2018), Antibiotic-resistant pathogenic Escherichia coli isolated from rooftop rainwater-harvesting tanks in the Eastern Cape, South Africa. International Journal of Environmental research and Public Health 15, Article 892. DOI:https://doi.org/10.3390/ijerph15050892 .

11. Muthama P.N. (2012), Test results, [online], URL: https://docs.wixstatic.com/ugd/731132_7c3fa6f2063d40f88b35b53cef9a7afe.pdf. Accessed on 17.01.2019

12. Naranjo J.E., Gerba C.P. (2013), Test results, [online], URL: https://docs.wixstatic.com/ugd/731132_5b9f71a25c844f1fb38ae2e2e63e28ab.pdf. Accessed on 15.11.2017.

13. Nondlazi S., Ngqwala N.P., Zuma B.M., Tandlich R. (2017), Investigating the viability and performance of the pilot scale fly ash/lime filter tower for onsite greywater treatment. Desalination and Water Treatment 91: 349-364. DOI: https://doi.org/10.5004/dwt.2017.21461.

14. Opare S. (2012), Rainwater harvesting: an option for sustainable rural water supply in Ghana. Geojournal, 77(5), 695-705. DOI: https://doi.org/10.1007/s10708-011-9418-6.

15. Rygaard, M., Binning, P.J., Albrechtsen, H-J. (2011). Increasing urban water selfsufficiency: new era, new challenges. Journal of Environmental Management, 92:185194. DOI: https://doi.org/10.1016/j.jenvman.2010.09.009.

16. Sallis P. (2010), Test results, [online], URL: https://docs.wixstatic.com/ugd/731132_81ddf8f90069428385344449cf3c2f8e.pdf. [Accessed 1411 2017].

17. Sturm, M., Zimmermann, M., Schütz, K., Urban, W. \& Hartung, H. (2009). Rainwater harvesting as an alternative water resource in rural sites in central northern Namibia. Physics and Chemistry of the Earth, 34, 776-785.

18. Tandlich R., Luyt C.D., Ngqwala N.P. (2014), A community-based rainwater monitoring and treatment programme in Grahamstown, South Africa. Journal of Hydrocarbons, Mines and Environmental Research 5(1): 46-51 (no DOI available).

19. Tandlich R., Luyt C.D., Gordon A.K., Srinivas C.S. (2012), Concentrations of indicator organisms in the stored rainwater in the Makana Municipality, South Africa.. 2012 "Air and Water - Components of the Environment" Conference Proceedings, Cluj-Napoca, Romania, p. 89-96, (ISSN: 2067-743X), http://aerapa.conference.ubbcluj.ro/wordpress/en/previous-conferences/.

20. United Nations Environment Programme. (2016), Rainwater harvesting and utilization. [online], URL: http://www.unep.or.jp/ietc/publications/urban/urbanenv2/index.asp. Accessed on 16.10.2016.

21. World Health Organization. (WHO, 2011). WHO Guidelines for drinking-water quality, fourth edition. [online], URL: https://www.who.int/water_sanitation_health/publications/2011/dwq_guidelines/en/. Accessed on 26.05.2017. 